Article

\title{
Polydopamine Nanoparticles for Combined Chemo- and Photothermal Cancer Therapy
}

\author{
Zhijun Zhu ${ }^{1}$ and Ming Su ${ }^{1,2, *}$ \\ 1 Department of Chemical Engineering, Northeastern University, Boston, MA 02115, USA; \\ zhuzhujun001@gmail.com \\ 2 Wenzhou Institute of Biomaterials and Engineering, Wenzhou Medical University, Chinese Academy \\ of Science, Wenzhou 325001, China \\ * Correspondence: m.su@northeastern.edu
}

Received: 5 June 2017; Accepted: 26 June 2017; Published: 29 June 2017

\begin{abstract}
Cancer therapy with two different modalities can enhance treatment efficacy and reduce side effects. This paper describes a new method for combined chemo- and photothermal therapy of cancer using poly dopamine nanoparticles (PDA-NPs), where PDA-NPs serve not only as a photothermal agent with strong near infrared absorbance and high energy conversion efficiency, but also as a carrier to deliver cisplatin via interaction between cisplatin and catechol groups on PDA-NPs. Polyethylene glycol (PEG) was introduced through Michael addition reaction to improve the stability of PDA-NPs in physiological condition. A remarkable synergistic therapeutic effect has been achieved compared with respective single treatments. This work suggests that the PDA-based nanoplatform can be a universal scaffold for combined chemo- and photothermal therapy of cancer.
\end{abstract}

Keywords: polydopamine nanoparticles; photothermal; chemotherapy; cisplatin

\section{Introduction}

Cisplatin that contains platinum is used widely as a means of chemotherapy of cancer [1,2], but its clinical use is limited by its severe toxic effect due to indiscriminate accumulation in normal and cancerous tissues, nonspecific interactions with extra and intracellular proteins, and drug resistance [3]. In parallel to efforts of mitigating toxicity of cisplatin by modifying its chemical structure, an alternate approach is to use delivery vehicles that could overcome these limitations and specifically target cancerous cells [4]. Many carrier systems such as gold [5,6], carbon [7,8], silica $[9,10]$, and polymer $[11,12]$ have been developed, but the long-term toxicity of these carriers remains an issue [13]. A nature-inspired biopolymer, melanin-liked polydopamine (PDA) that has excellent biocompatibility [14-16], and free-radical-scavenging activity [17-19], has been explored as coating materials for gold nanorods [20,21], iron oxide nanoparticles [15,22-24], and as a substrate for photothermal agent [13], but the photothermal property of PDA nanoparticles has been overlooked. As a kind of semiconducting polymer [25], with a photothermal energy conversion efficiency of $40 \%$, PDA-NPs have shown promising applications in photothermal-based cancer therapy, which is emerging as a powerful technique in cancer therapy due to localized treatment and minimal invasiveness [26-29].

This paper reports a PDA-NPs based therapeutic platform, where PDA-NPs loaded with anticancer drug cisplatin have been prepared through a mild method. PDA-NPs serve not only as a photothermal agent due to strong near infrared absorption and high photothermal energy conversion efficiency, but also as a carrier to load cisplatin via the interaction between cisplatin and catechol groups on PDA-NPs. Conjugation of cisplatin onto PDA-NPs has been achieved by mixing PDA-NPs and cisplatin in minutes. Polyethylene glycol (PEG), as a Food and Drug Administration (FDA) approved polymer has been introduced via a Michael addition reaction to improve the biocompatibility of the 
nanoplatform and prolong the circulation time of PDA-NPs in physiological condition. The anticancer drug cisplatin has been loaded onto PDA-NPs through the chelation interaction between cisplatin and catechol groups on PDA-NPs. A remarkable synergistic therapeutic effect is observed when compared with respective single treatments. This work suggests that PDA-NPs can serve as a drug delivery platform for combined chemo- and photothermal therapy.

\section{Materials and Methods}

Sodium dihydrogen phosphate $\left(\mathrm{NaH}_{2} \mathrm{PO}_{4}\right)$, sodium hydrogen phosphate $\left(\mathrm{Na}_{2} \mathrm{HPO}_{4}\right)$, ethanol and ammonia aqueous solution (28-32\%) were from Deutsche Bahn (Berlin, Germany). Dulbecco's modified eagle's medium (DMEM), fetal bovine serum (FBS) and phosphate buffered saline (PBS) were from Corning. Methyl thiazolyl tetrazolium (MTT), cis-diamminedichlorido-platinum (II) (cisplatin, CP) and $o$-Phenylenediamine (OPDA) were obtained from Alfa (Tewksbury, MA, USA). Dimethylsulfoxide (DMSO), dopamine hydrochloride, poly(ethylene glycol) methyl ether thiol (PEG-SH, molecular weight $5000)$ and dialysis tube (MWCO = $2000 \mathrm{Da})$ were from Sigma (St. Louis, MO, USA).

PDA-NPs were made by injecting $2 \mathrm{~mL}$ of water containing $0.25 \mathrm{~g}$ of dopamine into a mixture of $20 \mathrm{~mL}$ of ethanol, $45 \mathrm{~mL}$ of water, and $1.5 \mathrm{~mL}$ of ammonia aqueous solution [26,30]. The mixture was stirred at room temperature for $24 \mathrm{~h}$, followed by centrifugation with the addition of ethanol and washing with water. The PDA-NPs were modified with PEG by mixing $2 \mathrm{~mL}$ of PDA-NPs (4 mg) with $0.4 \mathrm{~mL}$ of mPEG-SH (8 mg) in $10 \mathrm{mM}$ Tris buffer ( $\mathrm{pH} 8.5)$ with overnight stirring. The PEGylated PDA-NPs were further purified by repeat centrifugation and dispersed in water. A JEOL JEM-1010 transmission electron microscope (TEM, JEOL, Tokyo, Japan) with $80 \mathrm{kV}$ accelerating voltage was used to collect TEM images. The hydrated size and zeta potential were measured on a Malvern zetesizer (ZS6300, Malvern, Worcestershire, UK). UV-vis spectra were taken on Varian Cary 4000 spectrophotometer (Agilent, Santa Clara, CA, USA).

An amount of $20 \mathrm{mg}$ of cisplatin was added into an aqueous solution containing $17 \mathrm{mg}$ of silver nitrate $(10 \mathrm{mg} / \mathrm{mL})$. The mixture was stirred in the dark for $24 \mathrm{~h}$ at room temperature. After moving white precipitation $(\mathrm{AgCl})$ by centrifugation at 10,000 rpm for $30 \mathrm{~min}$, cis-diamminediaqua platinum (II) solution was obtained, stored in the dark at $4{ }^{\circ} \mathrm{C}$ and used up within $24 \mathrm{~h}$. Cisplatin was loaded onto PDA-NPs by mixing $2 \mathrm{~mL}$ of PDA-NPs solution with cisplatin of desired amount under stirring for $30 \mathrm{~min}$ (denoted as PDA-PEG-CP), followed by centrifugation to remove extra drug.

The releasing profile of cisplatin was determined as follows. An amount of $5 \mathrm{~mL}$ of $2 \mathrm{mg} / \mathrm{mL}$ PDA-PEG-CP dispersion was loaded in a 2000 Da dialysis tube at $37{ }^{\circ} \mathrm{C}$ against $10 \mathrm{~mL}$ of PBS $(10 \mathrm{mM})$ at different $\mathrm{pH}$ (6.0 or 7.4), respectively. After a certain time, $200 \mu \mathrm{L}$ of dialysis solution was sampled, and $200 \mu \mathrm{L}$ of fresh buffer was added. The total dialysis solutions were replaced with $10 \mathrm{~mL}$ fresh buffer at $6 \mathrm{~h}, 12 \mathrm{~h}, 24 \mathrm{~h}$ and $48 \mathrm{~h}$, respectively. The amount of released cisplatin was measured via a modified literature procedure as follows [31]. Different aliquots $(0.02 \mathrm{~mL}, 0.05 \mathrm{~mL}, 0.08 \mathrm{~mL}, 0.1 \mathrm{~mL}$ and $0.15 \mathrm{~mL}$ of $10 \mu \mathrm{g} / \mathrm{mL}$, and $0.03 \mathrm{~mL}, 0.05 \mathrm{~mL}, 0.1 \mathrm{~mL}, 0.15 \mathrm{~mL}$ and $0.2 \mathrm{~mL}$ of $100 \mu \mathrm{g} / \mathrm{mL}$ ) of cisplatin aqueous solution were diluted to $200 \mu \mathrm{L}$ with water, followed by adding $200 \mu \mathrm{L}$ of $0.7 \mathrm{mg} / \mathrm{mL}$ OPDA (freshly prepared in dimethylformamide (DMF)) and another $200 \mu \mathrm{L}$ of phosphate buffer $(0.1 \mathrm{M}$, $\mathrm{pH}$ 6.8). The mixtures were mixed well and heated up to $100{ }^{\circ} \mathrm{C}$ for $10 \mathrm{~min}$ in a water bath in order to obtain a light green color solution. The solutions were cooled to room temperature and the absorbance was measured with a UV-vis spectrophotometer from 600 to $800 \mathrm{~nm}$. The concentration of as-made dialysis solution was determined to derive a calibration curve.

Henrietta Lacks (HeLa, human cervical cancer) cells were cultured in DMEM (containing 10\% FBS) in a humidified $5 \% \mathrm{CO}_{2}$ atmosphere at $37^{\circ} \mathrm{C}$. The in vitro cytotoxicities of PDA-PEG and PDA-PEG-CP on cells were tested as follows. Cells were seeded at a density of 8000 per well on a 96-well plate overnight and incubated in $100 \mu \mathrm{L}$ of medium containing nanoparticles for $24 \mathrm{~h}$. The cells were rinsed with PBS twice before adding fresh medium. An $808 \mathrm{~nm}$ diode laser at a power of $2 \mathrm{~W}$ was used to irradiate cell plates for a certain time to produce photo-thermal effect. The temperature of the solution was measured with an infrared camera. After irradiation, cells were incubated for another 24 h; MTT 
assay was used to examine cell viability as follows. An amount of $10 \mu \mathrm{L}$ of MTT ( $5 \mathrm{mg} / \mathrm{mL}$ in PBS) was added and cells were incubated for $4 \mathrm{~h}$ in the dark. The medium was then replaced with $100 \mathrm{~mL}$ of DMSO and the absorbance was monitored using a microplate reader at $550 \mathrm{~nm}$. The cells treated with the same procedure without adding MTT were used as the background control. The cell viability experiment was repeated three times and four parallel wells were used for each group.

\section{Results and Discussion}

Figure 1 shows the procedure of making PDA-PEG-CP nanoconstructs. PDA-NPs were made by oxidation and polymerization of dopamine in an alkaline solution, where the color of the solution rapidly turned to yellow (oxidation) and gradually changed to dark (polymerization). Figure 2a,b show the TEM image of PDA-NPs, where the nanoparticles with uniform size (148 nm) are obtained. The nanoparticles of this size remain in circulation for a long period of time, and efficiently accumulate in tumor tissues via enhanced permeability and retention (EPR) [32-34].

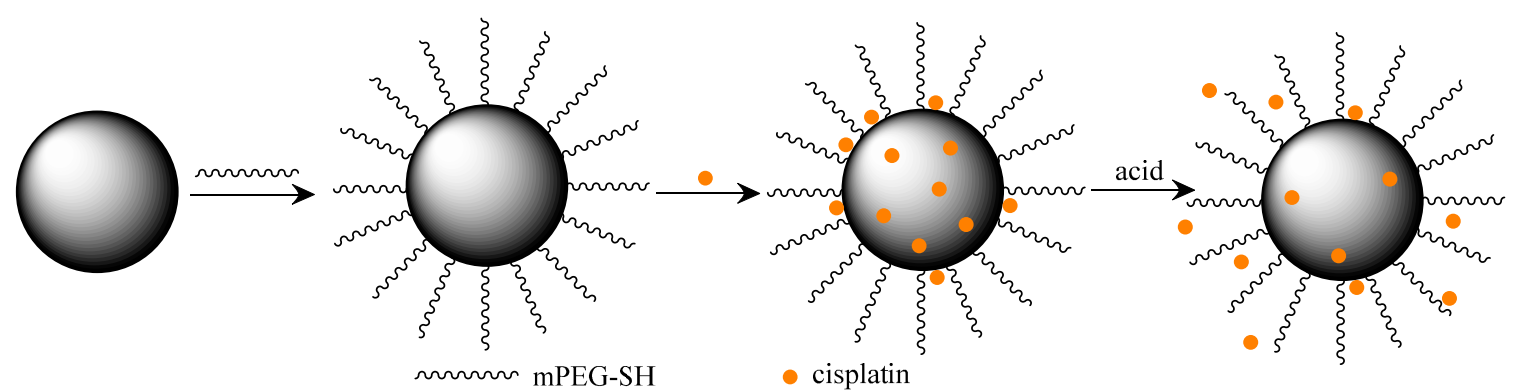

Figure 1. Scheme of loading cisplatin onto polyethylene glycol modified polydopamine nanoparticles (PDA-PEG-CP).

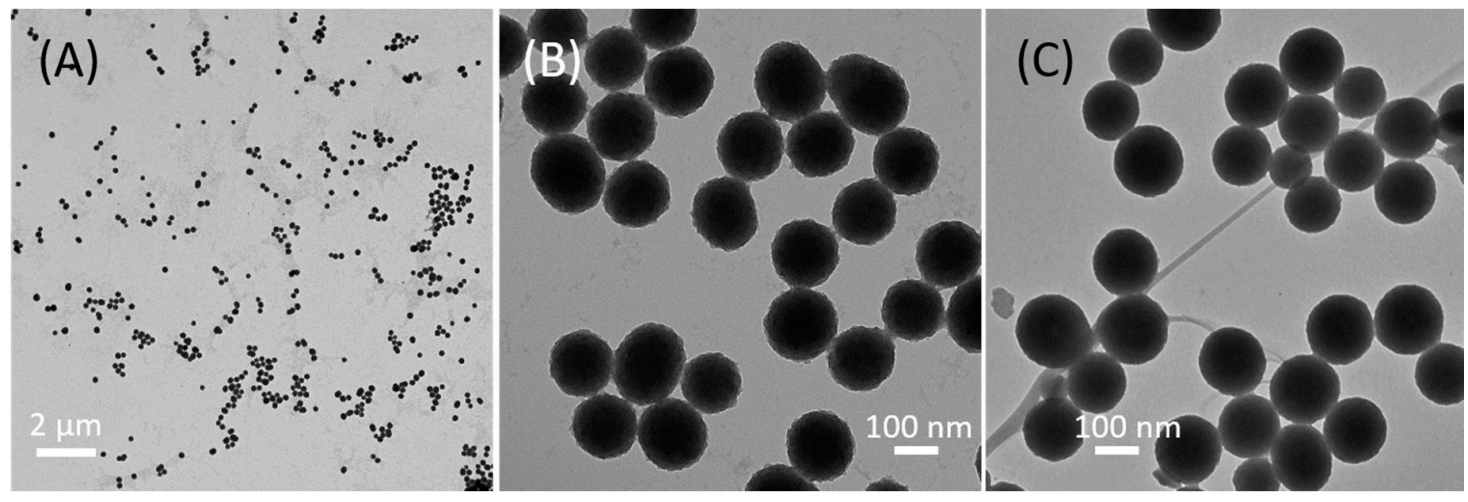

Figure 2. TEM images of polydopamine nanoparticles (PDA NPs) (A,B) with different magnifications and PDA NPs loaded cisplatin (PDA-PEG-CP) (C).

Figure 3a shows vis-NIR spectra of PDA-NPs, where a strong absorption in the near infrared wavelength region can be found at $800 \mathrm{~nm}$ (inset). The photothermal effect of PDA NPs of various concentrations under $808 \mathrm{~nm}$ laser radiation is tested with PBS as a negative control. Figure $3 \mathrm{~b}$ shows the temperature change profile of $0.2 \mathrm{~mL}$ PBS containing different concentrations of PDA-NPs, revealing the concentration-dependent photothermal effect. The temperature increased with the irradiation time for all the samples, and a higher concentration of PDA NPs leads to a more rapidly increasing temperature (Figure 3b). Take $200 \mu \mathrm{g} / \mathrm{mL}$ of PDA NPs for example; after $500 \mathrm{~s}$ of irradiation, the temperature increased by $29.6{ }^{\circ} \mathrm{C}$, while the negative control (PBS) increased only $4.6^{\circ} \mathrm{C}$ under the same condition. The rapid temperature change is due to the relatively high absorption coefficient $\left(7.3 \times 10^{8} \mathrm{M}^{-1} \mathrm{~cm}^{-1}\right)$ and photothermal efficiency (about 40\%) at $808 \mathrm{~nm}$ of PDA NPs [26]. 

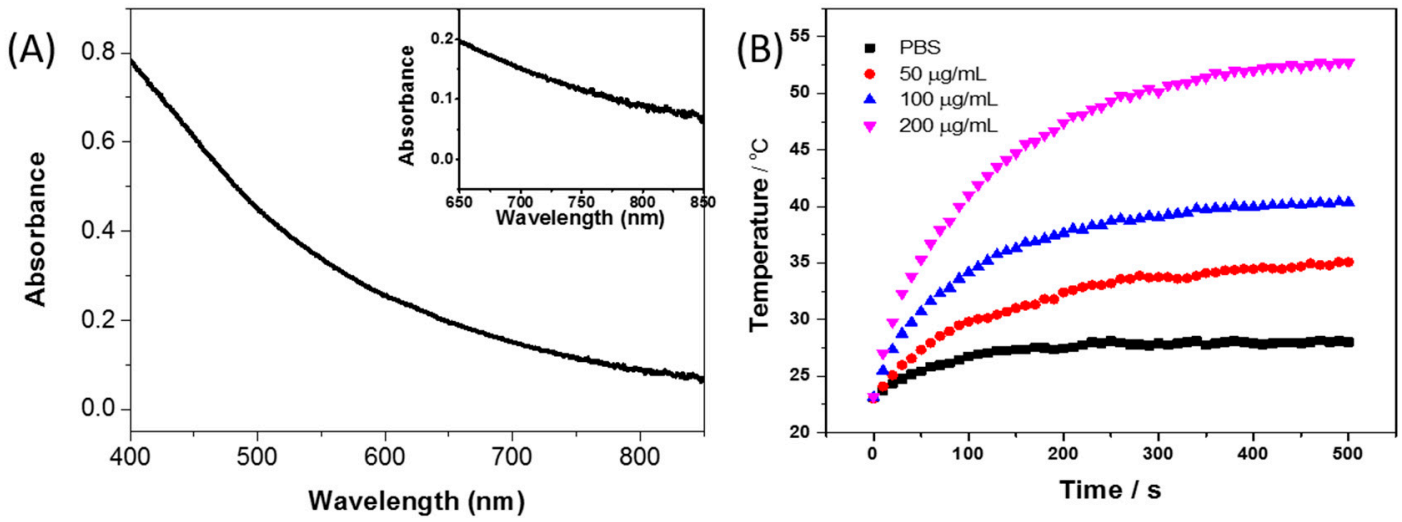

Figure 3. Absorbance spectrum (A) and enlarged image (inset) of PDA NPs. Temperature changes (B) of phosphate buffered saline (PBS) and PDA NPs of various concentrations under $808 \mathrm{~nm}$ laser irradiation $\left(2 \mathrm{~W} / \mathrm{cm}^{2}\right)$.

PDA-NPs were modified with mPEG-SH to enhance their circulation in physiological condition and facilitate their accumulation at tumor sites [35-37]. A Michael addition reaction was used to conjugate the thiol of PEG and $\alpha, \beta$-unsaturated carbonyl on PDA [38]. The zeta potential of PDA decreased from -35.4 to $-6.9 \mathrm{mV}$ after PEGylation, confirming the successful conjugation of PEG on the PDA-NPs.

With abundant PDA groups on the surface, PDA-NPs can deliver the drug through electrostatic interaction, coordination and $\pi-\pi$ interactions [39]. Cisplatin, a widely used anticancer drug was loaded onto the PEG-PDA NPs via the interaction between the platinum atom of cisplatin and catechol groups of PDA, and the nanoparticles were denoted as PEG-PDA-CP. The morphology and size of the NPs did not show obvious change between PDA and PDA-PEG-CP NPs, as seen in Figure 2b,c. The amount of cisplatin in the PEG-PDA NPs was measured to be $20 \%(\mathrm{~m} / \mathrm{m})$ using the OPDA method [31].

To study the release profile of cisplatin, PDA-PEG-CP solutions were suspended in PBS of different $\mathrm{pH}$ at $37^{\circ} \mathrm{C}$. The released cisplatin was quantified with an established method [31]. The formation of the complex of o-phenylenediamine (OPDA) and cisplatin was achieved by incubating OPDA and cisplatin in DMF spiked phosphate buffer at $100{ }^{\circ} \mathrm{C}$ for $10 \mathrm{~min}$. The resulting solution showed a maximum absorbance at $705 \mathrm{~nm}$, while neither OPDA nor cisplatin alone showed absorbance at $705 \mathrm{~nm}$ after the same treatment (Figure $4 \mathrm{~b}$ ). With the increasing concentration of cisplatin, the absorbance peak of the complex raised accordingly (Figure 4c), which is consistent with a previous report [31]. As a result, there is a good linear relationship between the absorbance intensity and concentration of $200 \mu \mathrm{L}$ original cisplatin in the range of $0-100 \mu \mathrm{g} / \mathrm{mL}$ (Figure $4 \mathrm{~d}$ ). 
(A)<smiles>Nc1ccccc1N</smiles><smiles>NC1(N)Nc2ccccc2N1</smiles>

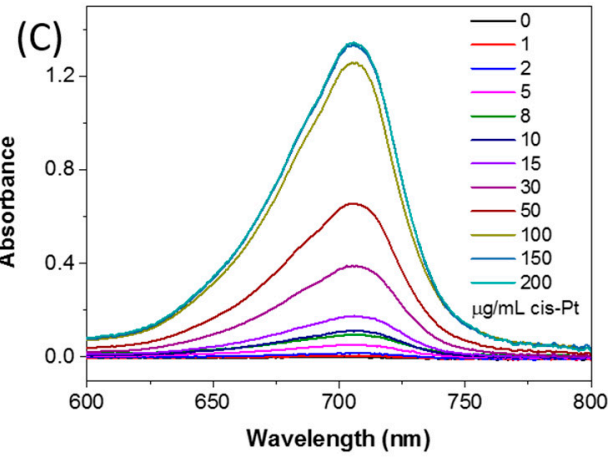

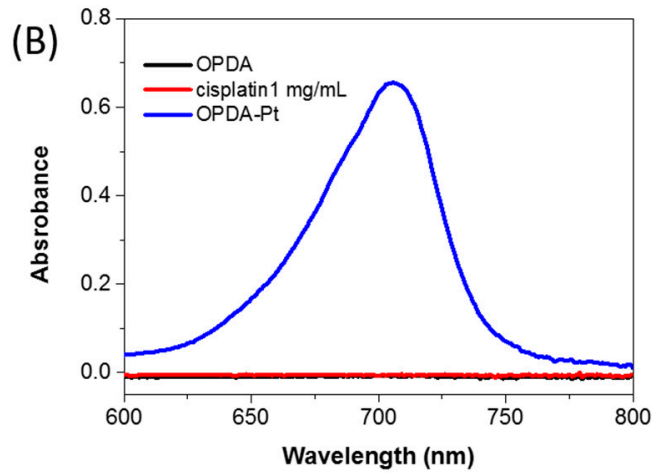

(D)

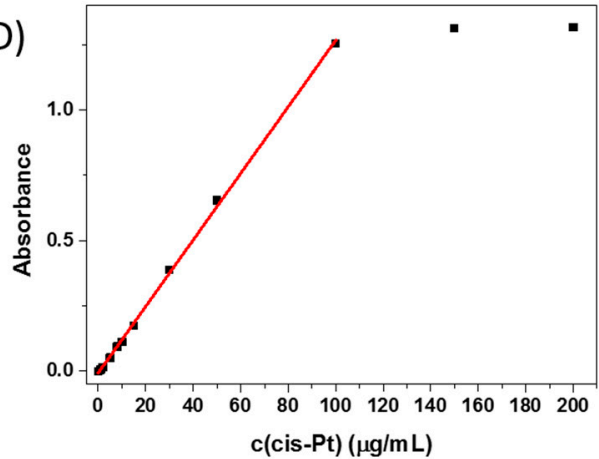

Figure 4. Reaction between o-phenylenediamine (OPDA) and cisplatin (A); the vis-NIR spectra of cisplatin, OPDA and the mixture of cisplatin and OPDA after incubation at $100{ }^{\circ} \mathrm{C}$ for $10 \mathrm{~min}(\mathrm{~B})$; the vis-NIR spectra of the complexes at different concentrations of cisplatin (C); and the calibration curve used to determine the original concentration of cisplatin stock solutions from optical absorbance (D).

It is essential to trigger cisplatin release from the drug delivery vehicles at tumor sites, thus keeping the overall therapeutic efficacy of the packaged drugs [40]. To this end, the release profile of cisplatin from the same batch of PDA-PEG-CP was evaluated through dialysis against saline buffered solutions at acidic ( $\mathrm{pH}$ 6.0) and physiological ( $\mathrm{pH}$ 7.4) conditions at $37{ }^{\circ} \mathrm{C}$ to mimic the acidic environment of the tumor site and cellular endosomes [41]. Cisplatin showed burst release within the first $1 \mathrm{~h}$ at both $\mathrm{pH}$ values. As expected, it showed a faster release at $\mathrm{pH} 6.0$ than at 7.4 throughout the remaining period (Figure 5). After $72 \mathrm{~h}, 33.3 \%$ of the loaded cisplatin was released at $\mathrm{pH} 7.4$; in comparison, at $\mathrm{pH} 6.0$, about $45 \%$ cisplatin was released in the first $36 \mathrm{~h}$ and $55 \%$ release was obtained after $72 \mathrm{~h}$. This acid-triggered drug release is due to the protonation of oxygen groups. In an acidic environment, $\mathrm{H}^{+}$would attack the lone electron pair of oxygen, leading to decomposing of drug-PDA complexes [21]. More importantly, at $\mathrm{pH}$ 6.0, it showed sustained release during the $72 \mathrm{~h}$ and a continuous release can be observed from 48 to $72 \mathrm{~h}$. The acid-enhanced drug release would enhance cancer therapy due to the acidic environment of most tumor cells $[42,43]$. 


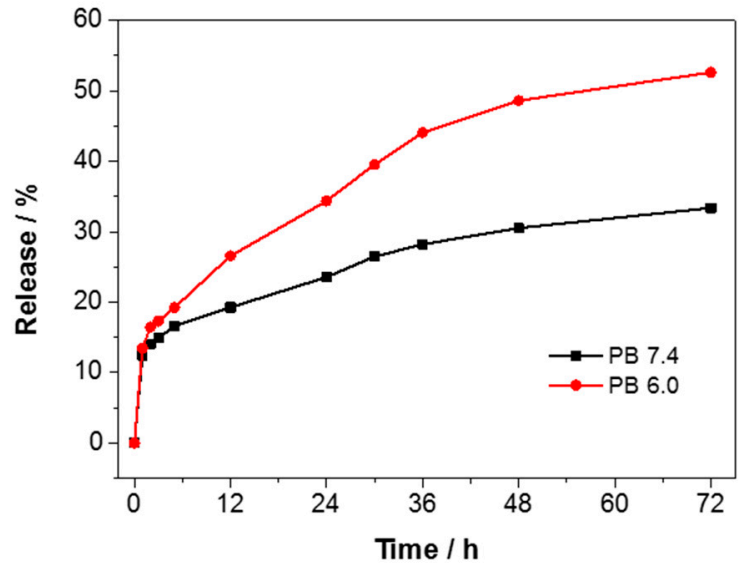

Figure 5. Cisplatin release curves against $10 \mathrm{mM}$ phosphate buffer (PB) at different $\mathrm{pH}$ values (7.4 and 6.0).

HeLa cells were used to assess the cytotoxicity of the drug delivery system. No obvious toxicity was observed after cells were incubated with PDA-PEG up to $100 \mu \mathrm{g} / \mathrm{mL}$ for $24 \mathrm{~h}$ (black histogram in Figure 6a). However, after $808 \mathrm{~nm}$ laser irradiation, apparent cell apoptosis can be obtained especially when the PDA-PEG concentration exceeds $20 \mu \mathrm{g} / \mathrm{mL}$ (red histogram in Figure $6 \mathrm{a}$ ). Up to $85 \%$ of cells were destroyed when incubated with $100 \mu \mathrm{g} / \mathrm{mL}$ of PDA-PEG under $808 \mathrm{~nm}$ laser irradiation. It indicates great potential in PDA-based photothermal therapy. To examine the chemotherapy effect, PDA-PEG/CP at different concentrations of drug were incubated with HeLa cells for $24 \mathrm{~h}$, then the cells were washed with PBS twice to remove non-internalized nanoparticles followed by $808 \mathrm{~nm}$ laser irradiation for $10 \mathrm{~min}$. It was found that cell viability decreased with increasing PAD-PEG/CP concentration, and over $70 \%$ of cells were killed when incubated with $100 \mu \mathrm{g} / \mathrm{mL}$ of cisplatin loaded onto polydopamine nanoparticles (PDA NPs) (Figure 6b). As expected, more cells were destroyed with laser irradiation after incubation with PDA-PEG-CP. Cell viability of combined therapy was found to be lower than the summation of photothermal and chemotherapy alone. The remarkably improved therapeutic effect may be attributed to the photothermal effect which not only kills cancer cells, but also effectively enhances the delivery and release of the drug into cells for improved chemotherapy. The results indicate a synergetic effect when chemotherapy and photothermal treatment are combined.
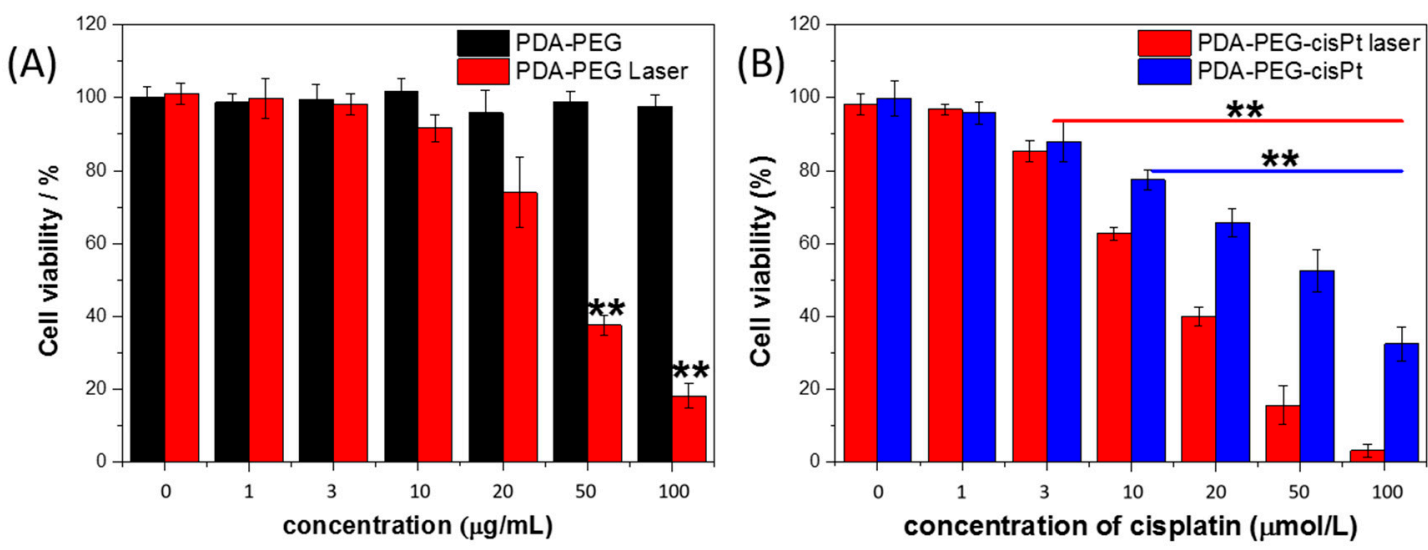

Figure 6. Viability of HeLa cells incubated at various concentrations of PDA-PEG (A) and PDA-PEG/CP (B) with or without laser irradiation $\left(2 \mathrm{~W} / \mathrm{cm}^{2}\right)$. ${ }^{* *} p<0.01$. 


\section{Conclusions}

A new nanoplatform based on nature-inspired polydopamine nanoparticles (PDA NPs) was created for combined photothermal and chemotherapy in cancer treatment. PDA showed great biocompatibility and molecular loading property, and enhanced photothermal conversion efficiency. A controlled amount of cisplatin was loaded onto PDA-PEG nanoparticles by chelation between platinum and catechol groups on PDA in minutes. This PDA-PEG/CP shows $\mathrm{pH}$-dependent drug release, excellent biocompatibility and a remarkable synergistic effect. The results suggest that the PDA-based nanoplatform shows great promise for clinical application.

Acknowledgments: This work was supported by a Director's New Innovator Award from National Institute of Health (1DP2EB016572-01).

Author Contributions: Zhijun Zhu and Ming Su conceived and designed the experiments; Zhijun Zhu performed the experiments; Zhiun Zhu and Ming Su analyzed the data and wrote the paper.

Conflicts of Interest: Authors declare no conflicts of interest.

\section{References}

1. Rosenberg, B.; Van Camp, L.; Krigas, T. Inhibition of Cell Division in Escherichia coli by Electrolysis Products from a Platinum Electrode. Nature 1965, 205, 698-699. [CrossRef] [PubMed]

2. Ma, P.; Xiao, H.; Li, C.; Dai, Y.; Cheng, Z.; Hou, Z.; Lin, J. Inorganic nanocarriers for platinum drug delivery. Mater. Today 2015, 18, 554-564. [CrossRef]

3. Paken, J.; Govender, C.D.; Pillay, M.; Sewram, V. Cisplatin-Associated Ototoxicity: A Review for the Health Professional. J. Toxicol. 2016, 2016, 1809394. [CrossRef] [PubMed]

4. Craig, G.E.; Brown, S.D.; Lamprou, D.A.; Graham, D.; Wheate, N.J. Cisplatin-Tethered Gold Nanoparticles that Exhibit Enhanced Reproducibility, Drug Loading, and Stability: A Step Closer to Pharmaceutical Approval? Inorg. Chem. 2012, 51, 3490-3497. [CrossRef] [PubMed]

5. Min, Y.; Mao, C.-Q.; Chen, S.; Ma, G.; Wang, J.; Liu, Y. Combating the Drug Resistance of Cisplatin Using a Platinum Prodrug Based Delivery System. Angew. Chem. Int. Ed. 2012, 51, 6742-6747. [CrossRef] [PubMed]

6. Ajnai, G.; Chiu, A.; Kan, T.; Cheng, C.-C.; Tsai, T.-H.; Chang, J. Trends of Gold Nanoparticle-based Drug Delivery System in Cancer Therapy. J. Exp. Clin. Med. 2014, 6, 172-178. [CrossRef]

7. Dhar, S.; Liu, Z.; Thomale, J.; Dai, H.; Lippard, S.J. Targeted Single-Wall Carbon Nanotube-Mediated Pt(IV) Prodrug Delivery Using Folate as a Homing Device. J. Am. Chem. Soc. 2008, 130, 11467-11476. [CrossRef] [PubMed]

8. Liu, Z.; Robinson, J.T.; Tabakman, S.M.; Yang, K.; Dai, H. Carbon materials for drug delivery \& cancer therapy. Mater. Today 2011, 14, 316-323.

9. Ahn, B.; Park, J.; Singha, K.; Park, H.; Kim, W.J. Mesoporous silica nanoparticle-based cisplatin prodrug delivery and anticancer effect under reductive cellular environment. J. Mater. Chem. B 2013, 1, 2829-2836. [CrossRef]

10. Bharti, C.; Nagaich, U.; Pal, A.; Gulati, N. Mesoporous silica nanoparticles in target drug delivery system: A review. Int. J. Pharm. Investig. 2015, 5, 124-133. [CrossRef] [PubMed]

11. Kapp, T.; Dullin, A.; Gust, R. Platinum(II)—Dendrimer Conjugates: Synthesis and Investigations on Cytotoxicity, Cellular Distribution, Platinum Release, DNA, and Protein Binding. Bioconjug. Chem. 2010, 21, 328-337. [CrossRef] [PubMed]

12. Priya James, H.; John, R.; Alex, A.; Anoop, K.R. Smart polymers for the controlled delivery of drugs-A concise overview. Acta Pharm. Sin. B 2014, 4, 120-127. [CrossRef] [PubMed]

13. Dong, Z.; Gong, H.; Gao, M.; Zhu, W.; Sun, X.; Feng, L.; Fu, T.; Li, Y.; Liu, Z. Polydopamine Nanoparticles as a Versatile Molecular Loading Platform to Enable Imaging-guided Cancer Combination Therapy. Theranostics 2016, 6, 1031-1042. [CrossRef] [PubMed]

14. Pahuja, R.; Seth, K.; Shukla, A.; Shukla, R.K.; Bhatnagar, P.; Chauhan, L.K.S.; Saxena, P.N.; Arun, J.; Chaudhari, B.P.; Patel, D.K.; et al. Trans-Blood Brain Barrier Delivery of Dopamine-Loaded Nanoparticles Reverses Functional Deficits in Parkinsonian Rats. ACS Nano 2015, 9, 4850-4871. [CrossRef] [PubMed] 
15. Losic, D.; Yu, Y.; Aw, M.S.; Simovic, S.; Thierry, B.; Addai-Mensah, J. Surface functionalisation of diatoms with dopamine modified iron-oxide nanoparticles: Toward magnetically guided drug microcarriers with biologically derived morphologies. Chem. Commun. 2010, 46, 6323-6325. [CrossRef] [PubMed]

16. Lynge, M.E.; van der Westen, R.; Postma, A.; Stadler, B. Polydopamine-a nature-inspired polymer coating for biomedical science. Nanoscale 2011, 3, 4916-4928. [CrossRef] [PubMed]

17. Ju, K.-Y.; Lee, Y.; Lee, S.; Park, S.B.; Lee, J.-K. Bioinspired Polymerization of Dopamine to Generate Melanin-Like Nanoparticles Having an Excellent Free-Radical-Scavenging Property. Biomacromolecules 2011, 12, 625-632. [CrossRef] [PubMed]

18. Saller, S.; Kunz, L.; Berg, D.; Berg, U.; Lara, H.; Urra, J.; Hecht, S.; Pavlik, R.; Thaler, C.J.; Mayerhofer, A. Dopamine in human follicular fluid is associated with cellular uptake and metabolism-dependent generation of reactive oxygen species in granulosa cells: Implications for physiology and pathology. Hum. Reprod. 2014, 29, 555-567. [CrossRef] [PubMed]

19. Liu, Y.; Ai, K.; Ji, X.; Askhatova, D.; Du, R.; Lu, L.; Shi, J. Comprehensive Insights into the Multi-Antioxidative Mechanisms of Melanin Nanoparticles and Their Application To Protect Brain from Injury in Ischemic Stroke. J. Am. Chem. Soc. 2017, 139, 856-862. [CrossRef] [PubMed]

20. Feng, B.; Xu, Z.; Zhou, F.; Yu, H.; Sun, Q.; Wang, D.; Tang, Z.; Yu, H.; Yin, Q.; Zhang, Z.; et al. Near infrared light-actuated gold nanorods with cisplatin-polypeptide wrapping for targeted therapy of triple negative breast cancer. Nanoscale 2015, 7, 14854-14864. [CrossRef] [PubMed]

21. Zhang, L.; Su, H.; Cai, J.; Cheng, D.; Ma, Y.; Zhang, J.; Zhou, C.; Liu, S.; Shi, H.; Zhang, Y.; et al. A Multifunctional Platform for Tumor Angiogenesis-Targeted Chemo-Thermal Therapy Using Polydopamine-Coated Gold Nanorods. ACS Nano 2016, 10, 10404-10417. [CrossRef] [PubMed]

22. Liao, N.; Wu, M.; Pan, F.; Lin, J.; Li, Z.; Zhang, D.; Wang, Y.; Zheng, Y.; Peng, J.; Liu, X.; et al. Poly (dopamine) coated superparamagnetic iron oxide nanocluster for noninvasive labeling, tracking, and targeted delivery of adipose tissue-derived stem cells. Sci. Rep. 2016, 6, 18746. [CrossRef] [PubMed]

23. Mumtaz, S.; Wang, L.S.; Abdullah, M.; Hussain, S.Z.; Iqbal, Z.; Rotello, V.M.; Hussain, I. Facile method to synthesize dopamine-capped mixed ferrite nanoparticles and their peroxidase-like activity. J. Phys. D Appl. Phys. 2017, 50, 11LT02. [CrossRef]

24. An, P.; Zuo, F.; Wu, Y.P.; Zhang, J.H.; Zheng, Z.H.; Ding, X.B.; Peng, Y.X. Fast synthesis of dopamine-coated $\mathrm{Fe}_{3} \mathrm{O}_{4}$ nanoparticles through ligand-exchange method. Chin. Chem. Lett. 2012, 23, 1099-1102. [CrossRef]

25. Pu, K.; Chattopadhyay, N.; Rao, J. Recent advances of semiconducting polymer nanoparticles in in vivo molecular imaging. J. Control. Release 2016, 240, 312-322. [CrossRef] [PubMed]

26. Liu, Y.; Ai, K.; Liu, J.; Deng, M.; He, Y.; Lu, L. Dopamine-Melanin Colloidal Nanospheres: An Efficient Near-Infrared Photothermal Therapeutic Agent for In Vivo Cancer Therapy. Adv. Mater. 2013, 25, 1353-1359. [CrossRef] [PubMed]

27. Yang, K.; Hu, L.; Ma, X.; Ye, S.; Cheng, L.; Shi, X.; Li, C.; Li, Y.; Liu, Z. Multimodal Imaging Guided Photothermal Therapy Using Functionalized Graphene Nanosheets Anchored with Magnetic Nanoparticles. Adv. Mater. 2012, 24, 1868-1872. [CrossRef] [PubMed]

28. Robinson, J.T.; Tabakman, S.M.; Liang, Y.; Wang, H.; Sanchez Casalongue, H.; Vinh, D.; Dai, H. Ultrasmall Reduced Graphene Oxide with High Near-Infrared Absorbance for Photothermal Therapy. J. Am. Chem. Soc. 2011, 133, 6825-6831. [CrossRef] [PubMed]

29. Guo, R.; Zhang, L.; Qian, H.; Li, R.; Jiang, X.; Liu, B. Multifunctional Nanocarriers for Cell Imaging, Drug Delivery, and Near-IR Photothermal Therapy. Langmuir 2010, 26, 5428-5434. [CrossRef] [PubMed]

30. Liebscher, J.; Mrówczyński, R.; Scheidt, H.A.; Filip, C.; Hădade, N.D.; Turcu, R.; Bende, A.; Beck, S. Structure of Polydopamine: A Never-Ending Story? Langmuir 2013, 29, 10539-10548. [CrossRef] [PubMed]

31. Basotra, M.; Singh, S.K.; Gulati, M. Development and Validation of a Simple and Sensitive Spectrometric Method for Estimation of Cisplatin Hydrochloride in Tablet Dosage Forms: Application to Dissolution Studies. ISRN Anal. Chem. 2013, 2013, 8. [CrossRef]

32. Blanco, E.; Shen, H.; Ferrari, M. Principles of nanoparticle design for overcoming biological barriers to drug delivery. Nat. Biotechnol. 2015, 33, 941-951. [CrossRef] [PubMed]

33. Iyer, A.K.; Khaled, G.; Fang, J.; Maeda, H. Exploiting the enhanced permeability and retention effect for tumor targeting. Drug Discov. Today 2006, 11, 812-818. [CrossRef] [PubMed]

34. Maeda, H.; Wu, J.; Sawa, T.; Matsumura, Y.; Hori, K. Tumor vascular permeability and the EPR effect in macromolecular therapeutics: A review. J. Control. Release 2000, 65, 271-284. [CrossRef] 
35. Ju, K.-Y.; Lee, J.W.; Im, G.H.; Lee, S.; Pyo, J.; Park, S.B.; Lee, J.H.; Lee, J.-K. Bio-Inspired, Melanin-Like Nanoparticles as a Highly Efficient Contrast Agent for T1-Weighted Magnetic Resonance Imaging. Biomacromolecules 2013, 14, 3491-3497. [CrossRef] [PubMed]

36. Pelaz, B.; del Pino, P.; Maffre, P.; Hartmann, R.; Gallego, M.; Rivera-Fernández, S.; de la Fuente, J.M.; Nienhaus, G.U.; Parak, W.J. Surface Functionalization of Nanoparticles with Polyethylene Glycol: Effects on Protein Adsorption and Cellular Uptake. ACS Nano 2015, 9, 6996-7008. [CrossRef] [PubMed]

37. Yang, C.; Ding, X.; Ono, R.J.; Lee, H.; Hsu, L.Y.; Tong, Y.W.; Hedrick, J.; Yang, Y.Y. Brush-Like Polycarbonates Containing Dopamine, Cations, and PEG Providing a Broad-Spectrum, Antibacterial, and Antifouling Surface via One-Step Coating. Adv. Mater. 2014, 26, 7346-7351. [CrossRef] [PubMed]

38. Lee, H.; Dellatore, S.M.; Miller, W.M.; Messersmith, P.B. Mussel-Inspired Surface Chemistry for Multifunctional Coatings. Science 2007, 318, 426-430. [CrossRef] [PubMed]

39. Seiffert, S.; Sprakel, J. Physical chemistry of supramolecular polymer networks. Chem. Soc. Rev. 2012, 41, 909-930. [CrossRef] [PubMed]

40. Lee, S.-M.; O'Halloran, T.V.; Nguyen, S.T. Polymer-Caged Nanobins for Synergistic Cisplatin-Doxorubicin Combination Chemotherapy. J. Am. Chem. Soc. 2010, 132, 17130-17138. [CrossRef] [PubMed]

41. Casey, J.R.; Grinstein, S.; Orlowski, J. Sensors and regulators of intracellular pH. Nat. Rev. Mol. Cell. Biol. 2010, 11, 50-61. [CrossRef] [PubMed]

42. Estrella, V.; Chen, T.; Lloyd, M.; Wojtkowiak, J.; Cornnell, H.H.; Ibrahim-Hashim, A.; Bailey, K.; Balagurunathan, Y.; Rothberg, J.M.; Sloane, B.F.; et al. Acidity Generated by the Tumor Microenvironment Drives Local Invasion. Cancer Res. 2013, 73, 1524-1535. [CrossRef] [PubMed]

43. Tannock, I.F.; Rotin, D. Acid pH in Tumors and Its Potential for Therapeutic Exploitation. Cancer Res. 1989, 49, 4373-4384. [PubMed]

(C) 2017 by the authors. Licensee MDPI, Basel, Switzerland. This article is an open access article distributed under the terms and conditions of the Creative Commons Attribution (CC BY) license (http:/ / creativecommons.org/licenses/by/4.0/). 